\title{
Testicular Cancer pT1 TNM Finding v8
}

National Cancer Institute

\section{Source}

National Cancer Institute. Testicular Cancer pT1 TNM Finding v8. NCI Thesaurus. Code C140213.

Testicular cancer which is limited to testis (including rete testis invasion) without lymphovascular invasion. (from AJCC 8th Ed.) 